\title{
Correction to: Promising anitidiabetic potential of Cuscuta reflexa leaves methanol extract in alloxaninduced diabetic rats
}

Ronia Mostofa ${ }^{1}$, Rayhana Begum", Hongbin Wang ${ }^{2}$, Mst. Marium Begum³ ${ }^{3}$ Rubaba Karim', Taslima Begum', Nur Alam Siddiquee ${ }^{1}$, Rebeka Sultana ${ }^{4}$, Sonia Sultana ${ }^{1}$, A. K. Lutful Kabir ${ }^{5}$, Sumaiya Alam ${ }^{1,6}$ and Tasnova Tasnim Nova ${ }^{3}$

\section{Correction to: Clin Phytosci 6, 26 (2020) https://doi.org/10.1186/s40816-020-00169-w}

Following publication of the original article [1], the authors identified an error in the author name of Tasnova Tasnim Nova.

The incorrect author name is: Tasnuva Tasnim Nova. The correct author name is: Tasnova Tasnim Nova.

The author group has been updated above.

\section{Author details}

${ }^{1}$ Department of Pharmacy, Primeasia University, Dhaka 1213, Bangladesh. ${ }^{2}$ Department of Pharmaceutical and Biomedical Sciences, College of Pharmacy, California Northstate University, California, USA. ${ }^{3}$ Department of Pharmacy, East West University, Aftabnagar, Dhaka 1212, Bangladesh. ${ }^{4}$ School of Molecular Medical Sciences, University of Nottingham, Nottingham, UK. ${ }^{5}$ Department of Pharmaceutical Technology, Faculty of Pharmacy, University of Dhaka, Dhaka 1000, Bangladesh. ${ }^{6}$ Department of Pharmaceutical Sciences, North South University, Dhaka 1229, Bangladesh.

Published online: 02 September 2020

\section{Reference}

1. Mostofa R, et al. Promising anitidiabetic potential of Cuscuta reflexa leaves
methanol extract in alloxaninduced diabetic rats. Clin Phytosci. 2020;6:26.

The original article can be found online at https://doi.org/10.1186/s40816020-00169-w.

* Correspondence: rayhana_kushum@yahoo.com

'Department of Pharmacy, Primeasia University, Dhaka 1213, Bangladesh

Full list of author information is available at the end of the article

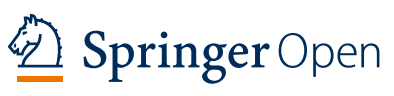

(c) The Author(s). 2020 Open Access This article is licensed under a Creative Commons Attribution 4.0 International License, which permits use, sharing, adaptation, distribution and reproduction in any medium or format, as long as you give appropriate credit to the original author(s) and the source, provide a link to the Creative Commons licence, and indicate if changes were made. The images or other third party material in this article are included in the article's Creative Commons licence, unless indicated otherwise in a credit line to the material. If material is not included in the article's Creative Commons licence and your intended use is not permitted by statutory regulation or exceeds the permitted use, you will need to obtain permission directly from the copyright holder. To view a copy of this licence, visit http://creativecommons.org/licenses/by/4.0/. 